\title{
Acid Soil Is Associated with Reduced Yield, Root Growth and Nutrient Uptake in Black Pepper (Piper nigrum L.)
}

\author{
Chao Zu ${ }^{1,2,3}$, Zhigang $\mathrm{Li}^{1,2,3}$, Jianfeng Yang1,2,3, Huan Yu ${ }^{1,2,3}$, Yan Sun ${ }^{1,2,3}$, Hongliang Tang ${ }^{4,5}$, \\ Russell Yost ${ }^{*}$, Huasong Wu $\mathbf{u}^{1,2,3^{*}}$ \\ ${ }^{1}$ Spice and Beverage Research Institute, Chinese Academy of Tropical Agricultural Sciences, Wanning, China \\ ${ }^{2}$ Key Laboratory of Genetic Resources Utilization of Spice and Beverage Crops, Ministry of Agriculture, Wanning, \\ China \\ ${ }^{3}$ Hainan Provincial Key Laboratory of Genetic Improvement and Quality Regulation for Tropical Spice and \\ Beverage Crops, Wanning, China \\ ${ }^{4}$ Key Laboratory of Plant-Soil Interaction, Ministry of Education, Beijing, China \\ ${ }^{5}$ Center for Resources, Environment and Food Security, China Agricultural University, Beijing, China \\ ${ }^{6}$ Department of Tropical Plant and Soil Science, University of Hawai'i at Manoa, Honolulu, USA \\ Email: ${ }^{*}$ rsyost@hawaii.edu, ${ }^{*}$ 13807622912@163.com
}

Received 16 February 2014; revised 16 March 2014; accepted 25 March 2014

Copyright @ 2014 by authors and Scientific Research Publishing Inc.

This work is licensed under the Creative Commons Attribution International License (CC BY).

http://creativecommons.org/licenses/by/4.0/

(c) (i) Open Access

\begin{abstract}
Low pH is a major limiting factor for the production of black pepper (Piper nigrum L.) in Hainan province. Black pepper gardens often exhibit a decrease in soil $\mathrm{pH}$ (to 5.5 - 5.0) on orchards with a multi-year production history. An exploratory hydroponic experiment was conducted to examine the effects of increasingly acid nutrient solution $\mathrm{pH}(7.0,5.5,4.0$, and 3.5) on seedling growth, tissue nutrient concentrations and root morphological traits. The results indicated that low $\mathrm{pH}$ may directly inhibit root development and function, limit $\mathrm{K}$, Ca and $\mathrm{Mg}$ absorption and reduce seedling growth. At pH 5.5, black pepper attained maximum growth, while the minimum growth occurred at pH 3.5. It can be concluded that low pH reduces plant growth and is associated with low root nutrient concentrations of $\mathrm{Ca}$ and $\mathrm{Mg}$, which may explain the decline of the yield in the seven pepper gardens of the Institute.
\end{abstract}

\section{Keywords}

Nutrient Concentration, Pepper Seedling Growth, pH, Root Morphology, Soil Acidification

\footnotetext{
${ }^{*}$ Corresponding authors.
} 


\section{Introduction}

Acid soils occupy approximately 30\% of the world's land area and restrain global agricultural production [1]. Soil acidification is a growing problem in soils of Chinese agricultural systems in the tropical region [2]. Numerous factors can result in soil acidification, such as large inputs of inorganic fertilizers, high rainfall, acid deposition and greenhouse gas. As the concentration of $\mathrm{H}^{+}$in the soil increases, it can inhibit root growth [3], disrupt the functions of the plasma membrane [4], cell wall [5], or by increasing $\mathrm{Al}^{3+}$ toxic levels [6]. Deficient levels of calcium $(\mathrm{Ca})$, magnesium $(\mathrm{Mg})$ and phosphorus $(\mathrm{P})$ are also frequent under low $\mathrm{pH}$ conditions.

Black pepper (Piper nigrum L.) is one of the important cash crops in the tropical agricultural regions of China. Hainan province, a major producer and exporter of black pepper in China, has 22,000 ha in cultivation and produces $36,000 \mathrm{Mg}$ of pepper berry annually, comprising $90 \%$ of the pepper production in China. Production of pepper provides income to approximately 1 million rural growers and has become an important tropical crop industry with output value of more than 1 billion Chinese yuan.

The suitable soil $\mathrm{pH}$ for pepper growth is 5.5 - 7.0 [7]. However, soil pH below 5.5 occupies approximately $50 \%$ of the typical pepper gardens in Hainan province [7]. Soil pH values less than 5.5 suggest the possible presence ot toxic levels of soil aluminum. Long term continuous planting of pepper may result in significant soil acidification [8]. Many pepper gardens with low soil pH have produced pepper for more than 30 years [7] [9]. In these gardens, pepper often showed poor growth, serious plant diseases and insect pests, nutrient deficiency, low yield and poor quality [8]. These problems become detrimental for the pepper industry. Therefore, it is urgent to investigate the effects of $\mathrm{pH}$ on pepper growth and nutrient absorption.

The objective of this study was to determine whether the decrease in pepper productivity of aging pepper gardens was associated with the decreased soil $\mathrm{pH}$ and how soil acidification affected pepper growth and nutrient absorption.

\section{Materials and Methods}

\subsection{Experiment 1: Survey of Institute Gardens with Pepper}

The study was conducted in Spice and Beverage Research Institute (SBRI) at the southeast of Hainan Province of China $\left(18^{\circ} 72^{\prime} \mathrm{N}-18^{\circ} 76^{\prime} \mathrm{N}, 110^{\circ} 19^{\prime} \mathrm{E}-110^{\circ} 22^{\prime} \mathrm{E}\right)$. The area is characterized by a tropical monsoon climate with an average temperature of $24.6^{\circ} \mathrm{C}$, while the absolute maximum may reach $38.7^{\circ} \mathrm{C}$ and the minimum may be $11.6^{\circ} \mathrm{C}$. Average annual precipitation of the area is $2150 \mathrm{~mm}$, and the annual mean relative humidity is $85 \%$.

The study area was comprised of a selection of seven gardens, which were divided into five age groups (10, 15, 20, 25 and 30 years of production) of black pepper (Piper nigrum L. cv. Reyin No.1) (Table 1). Row spacing was $2.5 \mathrm{~m}$, while spacing in the row was $2 \mathrm{~m}$. Within each garden five sampling locations were selected on an S-shape sampling configuration. A series of measurements were taken at each sampling location such as soil $\mathrm{pH}$ and pepper yield per plant. Four soil cores at each of the five sampling locations were composited for the soil sample to be analyzed. The soils were sampled at the $0-20 \mathrm{~cm}$ soil depth. Soil pH was measured using a ratio of $10 \mathrm{~g}$ soil to $25 \mathrm{ml}$ of water and stirred for 30 minutes.

Table 1. Survey of pepper gardens at the spice and beverage institute, Hainan Island, China.

\begin{tabular}{ccc}
\hline Pepper garden identification & Pepper garden age, yr & Number of plants reaching fruiting age \\
No. 13 & 28 & 424 \\
No. 14 & 28 & 382 \\
No. 15 & 21 & 35 \\
No. 19 & 15 & 312 \\
No. 21 & 15 & 10 \\
No. 22 & & 310 \\
No. 24 & & 377 \\
\hline
\end{tabular}




\subsection{Experiment 2: Solution Culture Experiment}

A solution culture experiment of black pepper (Piper nigrum L. cv. Reyin No. 1) seedlings was carried out to quantify the response of black pepper seedlings to increasing acidity. Seedlings were cultured in sand until the extensive development of roots. Seedlings were weighed and transferred to $15 \mathrm{~L}$ plastic pots with nutrient solution consisting of $\mathrm{K}_{2} \mathrm{SO}_{4}(750 \mu \mathrm{M}), \mathrm{MgSO}_{4}(650 \mu \mathrm{M}), \mathrm{KCl}(100 \mu \mathrm{M}), \mathrm{KH}_{2} \mathrm{PO}_{4}(250 \mu \mathrm{M}), \mathrm{Ca}\left(\mathrm{NO}_{3}\right)_{2}(2000 \mu \mathrm{M})$, Fe-EDTA $(100 \mu \mathrm{M}), \mathrm{H}_{3} \mathrm{BO}_{3}(100 \mu \mathrm{M}), \mathrm{MnSO}_{4}(1 \mu \mathrm{M}), \mathrm{ZnSO}_{4}(1 \mu \mathrm{M}), \mathrm{CuSO}_{4}(0.1 \mu \mathrm{M}),\left(\mathrm{NH}_{4}\right)_{6} \mathrm{Mo}_{7} \mathrm{O}_{24}(0.005$ $\mu \mathrm{M})$ [10]. The experimental design structure was a completely randomized combination of four solution $\mathrm{pH}$ treatments (3.5, 4.0, 5.5, and 7.0) with 8 replications. The $\mathrm{pH}$ of the nutrient solution was adjusted once a day by $\mathrm{HCl}$. Nutrient solutions were renewed every 4 days and continuously aerated with a pump. The pots were rerandomized every 20 days. Pepper seedlings were grown in a glasshouse at the SBRI with a photoperiod of 11 $\mathrm{h} \cdot \mathrm{d}^{-1}$, average temperature and photosynthetic photon flux density were $23^{\circ} \mathrm{C}$ and $234 \mu \mathrm{mol} \cdot \mathrm{m}^{-2} \cdot \mathrm{s}^{-1}$ at the shoot level and a relative humidity of $85 \%$.

After $65 \mathrm{~d}$ of growth, seedlings were harvested and separated into leaves, vines and roots. Fresh weight was determined. Root morphological parameters, such as total root length, root surface area, number of lateral roots, average diameter and volume of roots, were determined from scanned root samples with an Epson V700 scanner and the software WinRHIZO according to the method described by Liu et al. [10]. Dry weight of the root (WR) and shoot (WS) were measured after drying in an oven at $70^{\circ} \mathrm{C}$.

\subsection{Statistics}

Data were analyzed using regression and ANOVA using SAS (version 8.02) statistical software. Lines of best fit for the curves and error bars for the bar chart were calculated using GraphPad Prism (Version 5, GraphPad Software) [11].

\section{Results}

\subsection{Variation in Soil pH with Pepper Garden Age}

Across the seven gardens, soil $\mathrm{pH}$ significantly declined with increasing garden age $(P=0.018)$ (Figure 1$)$. According to the regression equation initial $\mathrm{pH}$ was approximately 5.84, while soil in 10-year-old orchards averaged 5.64, and 15-year-old gardens were characterized by a $\mathrm{pH}$ of 5.54. The 28-year-old garden averaged $\mathrm{pH}$ 5.28 .

\subsection{Pepper Seedling Response to Reduced pH (Solution Culture Experiment)}

\subsubsection{Fresh Weight Growth}

Fresh weight (shoot plus root) growth decreased significantly with decreasing solution pH. Pepper accumulated the maximum fresh weight of both shoots and roots (average $90.1 \mathrm{~g}$ ) at pH 5.5 (Figure 2), and a minimum fresh

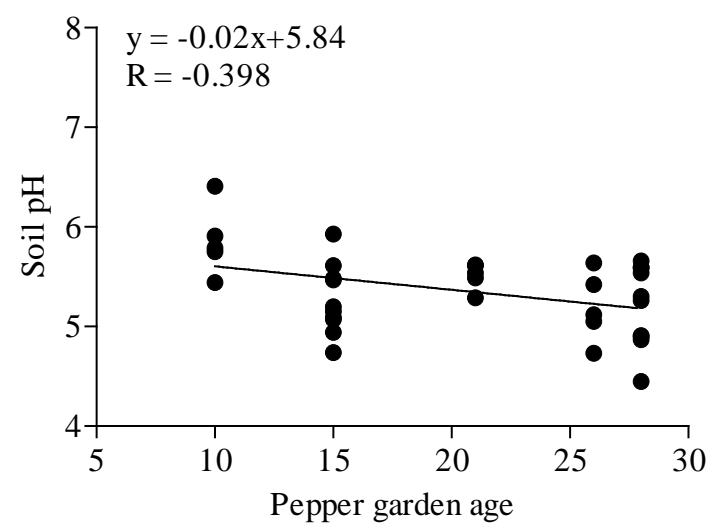

Figure 1. Variation in soil $\mathrm{pH}$ with planting year across seven pepper gardens at the SBRI, Hainan Island, China. 
weight (average $56.5 \mathrm{~g}$ ) at $\mathrm{pH}$ 3.5. There was no significant difference in fresh weight between $\mathrm{pH} 7$ and $\mathrm{pH}$ 5.5, both of which were much higher than plant fresh weight at $\mathrm{pH} 3.5$. At $\mathrm{pH} 4.0$, the fresh weight was much lower (68.3 g) compared with the weight in solutions of $\mathrm{pH} 5.0$ (90.1 g). There was no significant difference of fresh weight between $\mathrm{pH} 4.0$ and $\mathrm{pH} 3.5$ (Figure 2).

\subsubsection{Black Pepper Shoot and Root Growth and Nutrient Concentrations in Response to Solution $\mathrm{pH}$}

The effects of solution $\mathrm{pH}$ on root and shoot fresh weights are also shown in Table 2. Low pH decreased root

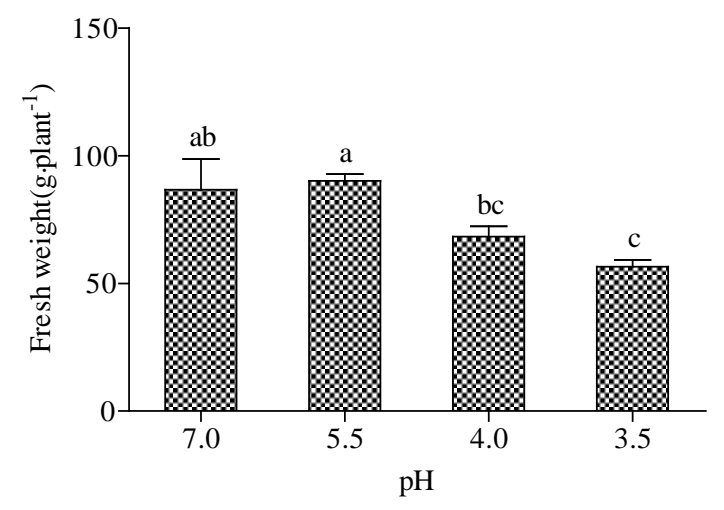

Figure 2. Growth yield of Piper nigrum L. cultured with four solution pHs (3.5, 4.0, 5.5, 7.0). Error bars indicate the standard error of the mean $(\mathrm{n}=3)$; columns not sharing the same letter indicate significant differences according to the ANOVA in SAS $(P=0.05)$.

Table 2. Pepper (Piper nigrum, L.) seedling fresh weight and nutrient concentrations in the root and shoot of black pepper at 65 days after transplanting as affected by solution $\mathrm{pH}$.

\begin{tabular}{|c|c|c|c|c|c|c|}
\hline \multirow{2}{*}{$\mathrm{pH}$} & \multirow{2}{*}{ Fresh weight (g·plant ${ }^{-1}$ ) } & \multicolumn{5}{|c|}{ Nutrient concentrations } \\
\hline & & $\mathrm{N}\left(\mathrm{mg} \cdot \mathrm{g}^{-1}\right)$ & $\mathrm{P}\left(\mathrm{mg} \cdot \mathrm{g}^{-1}\right)$ & $\mathrm{K}\left(\mathrm{mg} \cdot \mathrm{g}^{-1}\right)$ & $\mathrm{Ca}\left(\mathrm{mg} \cdot \mathrm{g}^{-1}\right)$ & $\operatorname{Mg}\left(\mathrm{mg} \cdot \mathrm{g}^{-1}\right)$ \\
\hline \multicolumn{7}{|c|}{ Root } \\
\hline 7.00 & $8.17 \pm 0.73$ & $33.77 \pm 1.54$ & $2.41 \pm 0.10$ & $10.24 \pm 0.87$ & $12.63 \pm 0.29$ & $3.69 \pm 0.13$ \\
\hline 5.50 & $7.77 \pm 0.20$ & $42.70 \pm 1.81$ & $3.05 \pm 0.09$ & $9.68 \pm 0.67$ & $8.90 \pm 0.27$ & $2.83 \pm 0.12$ \\
\hline 4.00 & $6.70 \pm 0.40$ & $43.89 \pm 1.06$ & $4.45 \pm 0.38$ & $3.80 \pm 1.20$ & $8.00 \pm 0.48$ & $1.70 \pm 0.32$ \\
\hline 3.50 & $5.77 \pm 0.62$ & $53.00 \pm 2.06$ & $3.71 \pm 0.37$ & $3.63 \pm 1.33$ & $5.54 \pm 0.33$ & $1.09 \pm 0.06$ \\
\hline $\mathrm{LSD}_{0.05}$ & 1.73 & 5.41 & 0.89 & 3.42 & 1.15 & 0.61 \\
\hline \multicolumn{7}{|c|}{ Coefficients of regression equation ${ }^{\mathrm{b}}$} \\
\hline $\mathrm{y}_{0}$ & 3.86 & 66.33 & 5.85 & -3.87 & -0.17 & -1.31 \\
\hline $\mathrm{a}$ & $0.65^{* *}$ & $-4.60^{* * *}$ & $-6.49^{* *}$ & $2.14^{* * *}$ & $1.79^{* * *}$ & $0.73^{* * *}$ \\
\hline $\mathrm{R}^{2}$ & 0.55 & 0.76 & 0.62 & 0.72 & 0.89 & 0.92 \\
\hline \multicolumn{7}{|c|}{ Shoot } \\
\hline 7.00 & $78.50 \pm 11.29$ & $27.70 \pm 0.99$ & $1.30 \pm 0.09$ & $21.78 \pm 0.27$ & $10.68 \pm 0.45$ & $4.09 \pm 0.57$ \\
\hline 5.50 & $82.33 \pm 0.83$ & $34.89 \pm 2.42$ & $1.66 \pm 0.27$ & $20.86 \pm 0.89$ & $10.51 \pm 0.40$ & $4.52 \pm 0.30$ \\
\hline 4.00 & $61.57 \pm 3.80$ & $37.58 \pm 2.83$ & $1.37 \pm 0.12$ & $25.61 \pm 1.07$ & $11.09 \pm 0.85$ & $3.86 \pm 0.07$ \\
\hline 3.50 & $50.73 \pm 3.35$ & $35.67 \pm 0.71$ & $1.62 \pm 0.19$ & $21.98 \pm 2.16$ & $8.22 \pm 0.23$ & $3.80 \pm 0.65$ \\
\hline $\mathrm{LSD}_{0.05}$ & 20.70 & 6.38 & $\mathrm{~ns}^{\mathrm{a}}$ & ns & 1.74 & ns \\
\hline \multicolumn{7}{|c|}{ Coefficients of regression equation } \\
\hline $\mathrm{y}_{0}$ & 27.95 & 46.12 & 1.73 & 25.61 & 8.00 & 3.47 \\
\hline $\mathrm{a}$ & $8.07^{*}$ & $-2.43^{* *}$ & $-0.05 \mathrm{~ns}$ & $-0.61 \mathrm{~ns}$ & $0.43 \mathrm{~ns}$ & $0.12 \mathrm{~ns}$ \\
\hline $\mathrm{R}^{2}$ & 0.50 & 0.51 & 0.05 & 0.11 & 0.19 & 0.05 \\
\hline
\end{tabular}

Each value represents the mean of three replicates \pm s.e.m. ${ }^{a}$ ns, no significance; ${ }^{* *}$ and ${ }^{* * *}$, significance at $P<0.01$ and $P<0.001$ level, respectively. ${ }^{\mathrm{b}}$ The general regression equation is $\mathrm{y}=\mathrm{y}_{0}+\mathrm{ax}$, where $\mathrm{y}$ is the molar ratio of nutrient and $\mathrm{x}$ is level of nutrient solution $\mathrm{pH}$. 
and shoot fresh weights of pepper seedlings $(P<0.01)$.The extremely low $\mathrm{pH}$ caused a greater decrease in shoot than in root weights. The smallest root and shoot fresh weights were observed at $\mathrm{pH} 3.5$ with decreases by $29 \%$ and $35 \%$ when compared with $\mathrm{pH}$ 7.0. However, little or no injurious effect was observed on root and shoot fresh weights at $\mathrm{pH} 5.5$.

Most of the variation of nutrient concentrations in both root and shoot came from different $\mathrm{pH}$ treatments (Table 2). Root nutrient concentrations differed with the nutrient. Compared to $\mathrm{pH}$ 7.0, $\mathrm{N}$ and $\mathrm{P}$ concentrations increased by $146 \%$ and $54 \%$ at $\mathrm{pH} 3.5$, respectively. In contrast, root potassium (K), calcium (Ca) and magnesium (Mg) decreased sharply with the decreasing $\mathrm{pH}$. At pH 3.5, K, Ca and Mg decreased 65\%, 56\% and 70\%, respectively.

\subsection{Prediction of Pepper nigrum L. Growth from Root Nutrient Concentrations}

The relationship between pepper growth and nutrient concentrations in roots varied with the nutrient (Figure 3). All nutrients were significantly related with growth except for $\mathrm{P}$. The relationship was strongest for $\mathrm{Mg}\left(\mathrm{R}^{2}=\right.$ $0.63)$, followed by $\mathrm{Ca}\left(\mathrm{R}^{2}=0.44\right)$ and $K\left(\mathrm{R}^{2}=0.44\right)$. However, growth was significantly negatively related with $\mathrm{N}$ concentration in root.

\subsection{Effects of Solution pH on Root Morphology}

Pepper root growth decreased consistently with decreased solution $\mathrm{pH}$ (Figure 4). The root morphology of pepper was sensitive to the change in solution $\mathrm{pH}$, with root length, surface area and number of laterals apparently

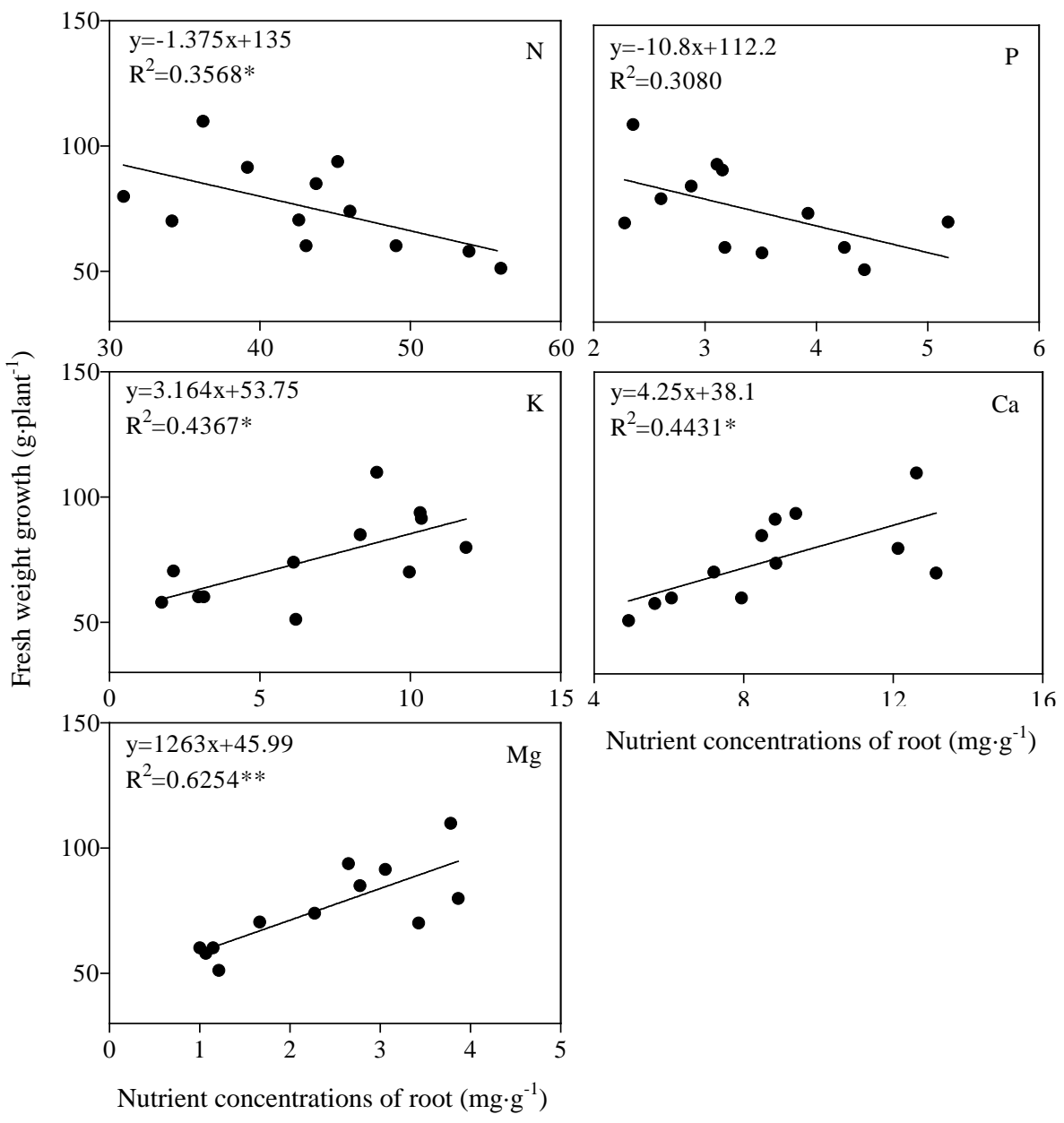

Figure 3. The prediction of Piper nigrum L. growth from root nutrient concentrations after 65 d growth. 

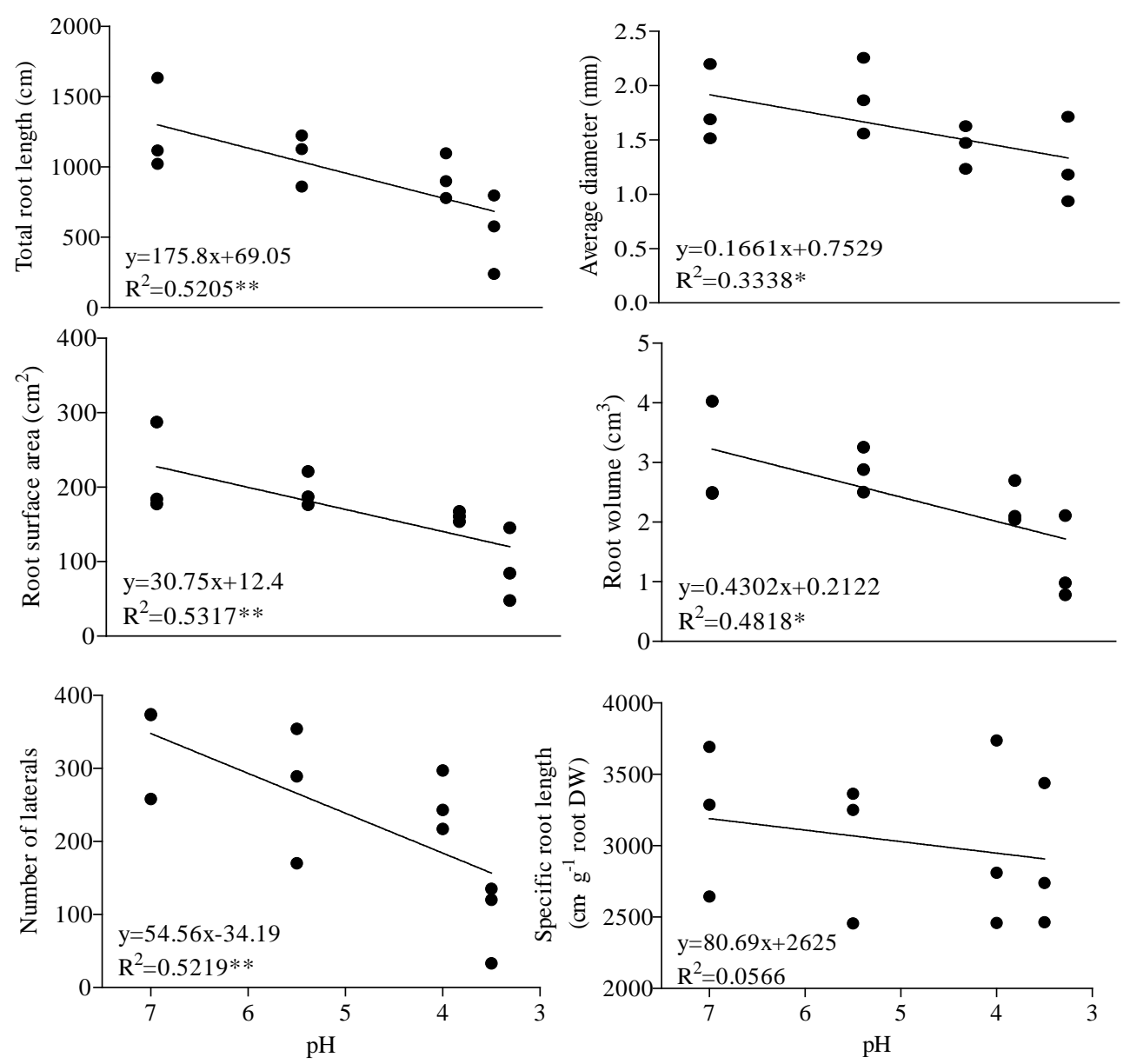

Figure 4. The relationship between solution $\mathrm{pH}$ with root morphological traits of Piper nigrum L. grown for $65 \mathrm{~d}$.

more sensitive to acidity than were root diameter and volume (data not shown). No significant difference was detected in terms of specific root length.

The increasing acidity was apparently toxic, reducing total root length by $15 \%, 26 \%$ and $57 \%$ at $\mathrm{pH} 5.5,4.0$ and 3.5, respectively (Figure 4). Pepper root surface area was reduced by $10 \%, 26 \%$ and $57 \%$, respectively. The surface area of root showed strongest negatively correlation with $\mathrm{pH}\left(\mathrm{r}^{2}=0.53\right)$. The number of laterals was reduced by $19 \%, 25 \%$ and $71 \%$ in lower $\mathrm{pH}$ solutions. Low $\mathrm{pH}$ also appeared to be inhibitory for root diameter and volume of roots but less so than for root length, surface area and laterals. The specific root length was not inhibited greatly under low $\mathrm{pH}$ (Figure 4).

\section{Discussion}

In the present study, soil $\mathrm{pH}$ exhibited a significant decrease with increasing pepper garden age. The results from a hydroponic experiment suggested that low $\mathrm{pH}$ considerably inhibited seedling fresh weight and root morphological parameters. Root nutrient concentrations of potassium, calcium and magnesium decreased, while nitrogen and phosphorus increased under low solution $\mathrm{pH}$. Indeed, a decrease in favorable root morphology does not mean a weak ability to acquire $\mathrm{N}$ and $\mathrm{P}$ from solution, as illustrated by the results. These differences are likely related to differences in $\mathrm{K}, \mathrm{Ca}$ and $\mathrm{Mg}$ absorption and fresh weight growth. We further explore this in the following sections to provide insights into the variation that we have obtained.

\subsection{The Soil pH Changed over Time}

In Hainan province, soil pH of common pepper garden appeared to decrease after many years of production. 
Large inputs of chemical fertilizers, particularly ammoniacal fertilizers, may be one of the key factors reducing $\mathrm{pH}$. White pepper production and fertilizer $\mathrm{N}$ applications reached 1 and $0.58 \mathrm{~kg} \cdot \mathrm{plant}^{-1}$ nationally in recent years, respectively, reducing 50\% and increases $154 \%$ as compared with year 1990 [12]. These applications result in large amounts of $\mathrm{N}$ fertiliser $\left(1,167 \mathrm{~kg} \cdot \mathrm{ha}^{-1}\right.$ each year). Furthermore, forms of applied $\mathrm{N}$ are usually urea-N, synthetic fertilizer-N (15-15-15) and manure-N, and, the percentage of inorganic-N is $77 \%$. High rates of $\mathrm{N}$ fertilization can cause soil acidification both directly and indirectly [13] [14]. Consequently the decreasing soil pH may have affected pepper growth.

\subsection{Fresh Weight Growth Inhibition under Low Solution $\mathrm{pH}$}

The solution culture showed that fresh weight growth of pepper seedlings was significantly inhibited at $\mathrm{pH} 4.0$ and 3.5. Potassium, calcium and magnesium concentrations of roots were also significantly inhibited under low solution $\mathrm{pH}$. A regression analysis was performed to examine the effect of root nutrient concentrations on the seedling fresh weight. The inhibition of $\mathrm{K}, \mathrm{Ca}$ and $\mathrm{Mg}$ uptake was associated with poor fresh weight growth.

\subsection{Root Growth and Nutrient Absorption Limitation in Response to Low pH Conditions}

Among the various plant parts, the roots are directly or indirectly affected by the $\mathrm{pH}$ of the growth medium. Low $\mathrm{pH}$ injury or $\mathrm{H}^{+}$injury is one of the factors responsible for growth retardation in acid conditions [5]. In the present study, decreasing growth medium $\mathrm{pH}$ significantly reduced root growth and nutrient content. Root growth was obviously inhibited by low $\mathrm{pH}$, especially surface area. Root surface area decreased linearly with declining solution $\mathrm{pH}(P=0.0071)$. Number of laterals and total root length increased significantly, but less than surface area with increasing $\mathrm{pH}(P=0.0080)$. Root diameter and volume showed significant positive correlation with $\mathrm{pH}(P<0.05)$. Excess $\mathrm{H}^{+}$in the growth medium affects plant growth by two processes: a) $\mathrm{H}^{+}$may cause injury to the root tissue, therefore root elongation, lateral branching, surface area and volume stretching were inhibited [5], and b) Specific effects on root ion fluxes via $\mathrm{H}^{+}$competition with base cations for uptake and $\mathrm{H}^{+}$ damage to the ion-selective carrier in root membranes. For example $\mathrm{H}^{+}$decreases the function of the plasma membrane and promotes $\mathrm{K}$ loss or the inhibition of $\mathrm{K}$ uptake, and consequently brings about poor root growth [5].

A decrease in the $\mathrm{K}, \mathrm{Ca}$ and $\mathrm{Mg}$ concentrations in seedling roots was observed under low $\mathrm{pH}$ conditions. A previous study showed that an increase in the hydrogen-ion concentration of the medium generally caused a decrease in the rate of cation absorption, probably as a result of competition between the similarly charged ions for binding and carrier sites [5]. The abnormal morphology caused by acidic conditions may be another reason for the reduced absorption of cations. Root $\mathrm{N}$ concentration decreased with increasing $\mathrm{pH}$ in the range of 3.5 - 7.0, however, plant $\mathrm{N}$ content did not appear to decrease.

\section{Conclusions}

The decline in soil $\mathrm{pH}$ with years under pepper production may correlate with high levels of $\mathrm{N}$ fertilization, which usually leads to reduced soil $\mathrm{pH}$. Solution culture studies of the effect of low solution $\mathrm{pH}$ indicated inhibition of Piper nigrum L. seedling growth and nutrient uptake in high $\mathrm{H}^{+}$conditions. Pepper seedling fresh weight was reduced 34\% at $\mathrm{pH} 3.5$ compared to $\mathrm{pH}$ 7.0. The root $\mathrm{K}$, Ca and $\mathrm{Mg}$ absorption were restricted by the low $\mathrm{pH}$. The decrease in fresh weight was clearly affected by the $\mathrm{K}, \mathrm{Ca}$ and $\mathrm{Mg}$ decline. The root morphology was significantly modified, usually reduced at the low $\mathrm{pH}$. Root elongation, lateral branching, surface area and volume stretching usually enhance the ability to take up nutrients of $\mathrm{K}, \mathrm{Ca}$ and $\mathrm{Mg}$ from acid solution. Alternatively, excessive $\mathrm{H}^{+}$decreases the function of the plasma membrane and promotes $\mathrm{K}$, Ca and $\mathrm{Mg}$ loss or the inhibition of $\mathrm{K}$, Ca and Mg uptake, and consequently brings about poor root growth.

Nutrient solution $\mathrm{pH}$ significantly reduced growth of pepper seedlings with most reduction occurring in the $\mathrm{pH}$ range from 4.0 to 3.5, according to minimal fresh weight, morphology of root and root $\mathrm{K}$, Ca, Mg concentrations. Outside this range, growth was progressively increased with suitable $\mathrm{pH}$ values. Determinations of root morphology should be the priority in evaluations of pepper regarding growth yield in response to $\mathrm{pH}$.

\section{Acknowledgements}

This work was supported by the Natural Science Foundation of China (grant nos. 31301857) and Natural 
Science Foundation of Hainan province (grant nos. 311084). We are grateful to Russell Yost for helpful comments on the manuscript and Hongliang Tang for helping with part of the statistical analyses. We also thank two anonymous reviewers for their constructive comments, which helped in improve the manuscript.

\section{References}

[1] Uexküll, H.R. and Mutert, E. (1995) Global Extent Development and Economic Impact of Acid Soils. Plant and Soil, 171, 1-15. http://dx.doi.org/10.1007/BF00009558

[2] Guo, J.H., Liu, X.J., Zhang, Y., Shen, J.L., Han, W.X., Zhang, W.F., Christie, P., Goulding, K.W.T., Vitousek, P.M. and Zhang, F.S. (2010) Significant Acidification in Major Chinese Croplands. Science, 327, 1008-1010. http://dx.doi.org/10.1126/science.1182570

[3] Polomski, J. and Kuhn, N. (2002) Root Research Methods. In: Waisel, Y., Eshel, A., Kafkafi U. and Dekker, M., Eds., Plant Roots: The Hidden Half (Third), New York, 313-314.

[4] Vitorello, V.A., Capaldi, F.R. and Stefanuto, V.A. (2005) Recent Advances in Aluminum Toxicity and Esistance in Higher Plants. Brazilian Journal of Plant Physiology, 17, 129-143. http://dx.doi.org/10.1590/S1677-04202005000100011

[5] Alam, S.M., Naqvi, S.S.M. and Ansari, R. (1999) Impact of Soil pH on Nutrient Uptake by Crop Plants. In: Pessarakli, M., Ed., Handbook of Plant and Crop Stress, New York, 51-60.

[6] Ma, J.F. (2007) Syndrome of Aluminum Toxicity and Diversity of Aluminum Resistance in Higher Plants. International Review of Cytology, 264, 225-252. http://dx.doi.org/10.1016/S0074-7696(07)64005-4

[7] Yang, J.F., Xing, G.Y., Sun, Y., Wang, H., Wu, H.S. and Zheng, W.Q. (2009) Analysis and Assessment of Soil Chemical Fertility in Typical Black Pepper Gardens in Hainan. Journal of Tropical Crops, 30, 1291-1294.

[8] Zu, C., Wu, H.S., Tan, L.H., Yu, H., Yang, J.F., Li, Z.G., et al. (2012) Analysis of Correlation between Soil pH and Nutrient Concentrations across Hainan Black Pepper Advantage Region. Chinese Journal of Tropical Crops, 33, 11741179.

[9] Xing, G.Y., Tan, L.H. and Lin, D. (2004) Pepper Plantation Soil Nutrient Status in Hainan. Journal of Tropical Crops, 25, 36-41.

[10] Liu, Y., Mi, G.H., Chen, F.J., Zhang, J.H. and Zhang, F.S. (2004) Rhizosphere Effect and Root Growth of Two Maize (Zea mays L.) Genotypes with Contrasting P Efficiency at Low P Availability. Plant Science, 167, 217-223. http://dx.doi.org/10.1016/j.plantsci.2004.02.026

[11] Clincha, R.L., Thevathasan, N.V., Gordon, A.M., Volk, T.A. and Sidders, D. (2009) Biophysical Interactions in a Short Rotation Willow Intercropping System in Southern Ontario, Canada. Agriculture, Ecosystems and Environment, 131, 61-69. http://dx.doi.org/10.1016/j.agee.2009.01.018

[12] Zhang, H.C. (2002) Pepper Nutrient and Fertilization Model Research. Journal of Yunnan Tropical Crops Science \& Technology, 25, 10-15.

[13] Juo, A.S.R., Dabiri, A. and Franzluebbers, K. (1995) Acidification of a Kaolinitic Alfisol under Continuous Cropping with Nitrogen Fertilization in West Africa. Plant and Soil, 171, 245-253. http://dx.doi.org/10.1007/BF00010278

[14] Matsuyama, N., Saigusa, M., Sakaiya, E., Tamakawa, K., Oyamada, Z. and Kudo, K. (2005) Acidification and Soil Productivity of Allophanic Andosols Affected by Heavy Application of Fertilizers. Soil Science and Plant Nutriention, 51, 117-123. http://dx.doi.org/10.1111/j.1747-0765.2005.tb00014.x 